\title{
Effects of hydroxy trace minerals on oxidative metabolism, cytological endometritis, and performance of transition dairy cows
}

\author{
T. Yasui, ${ }^{*}$ C. M. Ryan, ${ }^{*}$ R. O. Gilbert,† K. R. Perryman, $\ddagger$ and T. R. Overton*1 \\ *Department of Animal Science, and \\ †Department of Clinical Sciences, College of Veterinary Medicine, Cornell University, Ithaca, NY 14853 \\ ‡Micronutrients Inc., Indianapolis, IN 46231
}

\section{ABSTRACT}

Multiparous Holstein cows $(\mathrm{n}=60)$ were used to determine effects of supplementing hydroxy forms of $\mathrm{Zn}, \mathrm{Cu}$, and $\mathrm{Mn}$ compared with 2 other common supplementation strategies on oxidative metabolism, cytological endometritis, and performance of transition cows. After a 1-wk pretreatment period, cows were assigned randomly to 1 of 3 dietary treatments from 21 $\mathrm{d}$ before expected calving through $84 \mathrm{~d}$ postcalving. Dietary treatments administered by daily top-dressing included (1) inorganic sulfate forms of $\mathrm{Zn}, \mathrm{Cu}$, and Mn (ITM); (2) a blend (75:25) of sulfates and organic complexes of $\mathrm{Zn}, \mathrm{Cu}$, and $\mathrm{Mn}$ (ITM/OTM); and (3) hydroxy trace minerals (HTM) of Zn, Cu, and Mn. The resulting dietary concentrations of supplemental $\mathrm{Zn}$, $\mathrm{Cu}$, and $\mathrm{Mn}$ were similar among treatments and averaged 40,10 , and $27 \mathrm{mg} / \mathrm{kg}$, respectively, before calving and 59,15 , and $40 \mathrm{mg} / \mathrm{kg}$, respectively, after calving. Total concentrations of $\mathrm{Zn}, \mathrm{Cu}$, and $\mathrm{Mn}$ averaged 80, 16 , and $62 \mathrm{mg} / \mathrm{kg}$ during the prepartum period and 102,23 , and $75 \mathrm{mg} / \mathrm{kg}$, respectively, during the postpartum period. Overall, effects of treatment on milk yield and milk composition were not significant. Cows fed HTM during the prepartum period had higher body weight (BW) than those fed ITM during the prepartum period and had higher BW during the postpartum period than those fed the other treatments; however, BW change, body condition score, and body condition score change were not affected by treatment. Plasma total antioxidant capacity was lower in cows fed HTM than ITM but was not different from cows fed ITM/ OTM. Cows fed HTM tended to have lower concentrations of plasma thiobarbituric acid reactive substances than those fed ITM during the whole study period, but plasma thiobarbituric acid reactive substances were not different between HTM and ITM/OTM. Plasma haptoglobin was lower in cows fed HTM than ITM/OTM at 1 wk postpartum. Endometrial cytology 7 d postcalving

Received August 2, 2013.

Accepted February 22, 2014.

${ }^{1}$ Corresponding author: tro2@cornell.edu and cytological endometritis as assessed on $1 \mathrm{~d}$ between 40 and $60 \mathrm{~d}$ postcalving was not affected by treatment. In conclusion, supplementation with HTM sources of $\mathrm{Zn}, \mathrm{Cu}$, and $\mathrm{Mn}$ modulated plasma variables related to oxidative metabolism compared with supplementation with ITM; however, HTM and ITM/OTM resulted in similar responses. Furthermore, the source of trace minerals did not affect performance or uterine health in this experiment.

Key words: trace minerals, oxidative stress, cytological endometritis

\section{INTRODUCTION}

Trace minerals are important for many critical biological functions including immunity, oxidative metabolism, nutrient and energy metabolism, and reproductive function in dairy cows (NRC, 2001; Spears and Weiss, 2008). The specific roles of $\mathrm{Zn}, \mathrm{Cu}$, and $\mathrm{Mn}$ have received substantial attention in dairy cows, and studies have been conducted to evaluate effects of $\mathrm{Zn}, \mathrm{Cu}$, and $\mathrm{Mn}$ on productive and reproductive performance (Siciliano-Jones et al., 2008; Formigoni et al., 2011; Nemec et al., 2012). Specifically, decreased Zn status was demonstrated to be associated with higher rates of metritis, mastitis, and retained placenta (Enjalbert et al., 2006). Copper supplementation during the prepartum period and early lactation resulted in less severe clinical responses to intramammary Escherichia coli challenge during early lactation (Scaletti et al., 2003). Nemec et al. (2012) reported that supplementation of organic chelates of $\mathrm{Zn}, \mathrm{Cu}$, and $\mathrm{Mn}$ enhanced both innate and humoral immune responses in lactating cows

Oxidative stress is increased during the transition period due to high demands of metabolism (Sordillo and Aitken, 2009) and likely contributes to periparturient disorders, including metabolic diseases (Sharma et al., 2011). Bernabucci et al. (2005) reported that cows with higher plasma BHBA and NEFA concentrations had higher concentrations of reactive oxygen metabolites and thiobarbituric acid-reactive substances (TBARS) and lower levels of antioxidants in plasma during the transition period. Sordillo and Aitken (2009) suggested 
that oxidative stress during the transition period can be a major underlying cause of inflammatory and immune dysfunction in dairy cattle and that a significant relationship exists between antioxidant supplementation and decreased incidence of diseases around parturition. Because of their antioxidant function, trace minerals can contribute to counterbalancing oxidative stress, which could reduce metabolic and immune problems during the transition period.

Cytological endometritis (CE) is characterized by inflammation of the endometrium, which results in a significant reduction in reproductive performance in the absence of signs of clinical endometritis (Sheldon et al., 2009). Given the role of trace minerals in immune function, it is possible that their interaction with immunity and, hence, CE may underpin some of the responses of reproduction to trace mineral supplementation outlined above.

Substantial interest has focused on the potential to enhance the function of dairy cows by feeding trace mineral sources with greater bioavailability (NRC, 2001; Andrieu, 2008) or to maintain high function by feeding lower overall levels of trace minerals using these more bioavailable sources (Nocek et al., 2006). Indeed, recent research conducted by our research group suggested that trace mineral amount and source can modulate aspects of oxidative metabolism (Yasui et al., 2009). Hydroxy trace mineral sources (Micronutrients Inc., Indianapolis, IN) have shown higher bioavailability than sulfates in steers (Spears et al., 2004) and weanling pigs (Fry et al., 2012), but have not been evaluated in dairy cattle. In addition, the role of these and other trace mineral sources in the etiology of $\mathrm{CE}$ has not been elucidated. Therefore, the objectives of this experiment were to evaluate a new source of trace minerals with potentially higher bioavailability and determine whether trace mineral source affects aspects of oxidative metabolism, CE, and performance of cows during the transition period and early lactation.

\section{MATERIALS AND METHODS}

\section{Experimental Animals, Treatments, and Procedures}

All procedures involving animals were approved by the Cornell University Institutional Animal Care and Use Committee (Ithaca, NY) before the onset of the experiment. Sixty Holstein cows entering their second lactation or greater from the Cornell University Teaching and Research Center Dairy were moved to individual tie-stalls and enrolled in this experiment $28 \mathrm{~d}$ before expected calving and fed the same prepartum basal diet (Table 1). Cows were assigned to 1 of 3 treatments, with randomization restricted by previous lactation 305-d mature-equivalent milk production. Treatments were initiated $21 \mathrm{~d}$ before expected calving and continued through $84 \mathrm{~d}$ postcalving and consisted of the following: (1) inorganic sources based on sulfates of $\mathrm{Zn}, \mathrm{Cu}$, and Mn (ITM); (2) a blend (75:25) of sulfates and organic AA complexes of $\mathrm{Zn}, \mathrm{Cu}$, and $\mathrm{Mn}$ (ITM/OTM); and (3) hydroxy trace minerals (HTM) of $\mathrm{Zn}, \mathrm{Cu}$, and Mn (IntelliBond; Micronutrients Inc.). The blend ratio for the ITM/OTM treatment was determined based upon our observations of common strategies for trace mineral supplementation in the dairy industry. The target concentrations of supplemental $\mathrm{Zn}, \mathrm{Cu}$, and $\mathrm{Mn}$ across treatments were the same for both prepartum and postpartum periods: 60,15 , and $40 \mathrm{mg} / \mathrm{kg}$, respectively. Final total concentrations of $\mathrm{Zn}, \mathrm{Cu}$, and Mn based upon actual DMI during the prepartum and postpartum periods are provided in Table 2. Final total concentrations were similar across treatments and averaged 80,16 , and $62 \mathrm{mg} / \mathrm{kg}$ during the prepartum period and 102,23 , and $75 \mathrm{mg} / \mathrm{kg}$ during the postpartum period for $\mathrm{Zn}, \mathrm{Cu}$, and $\mathrm{Mn}$, respectively. The ration fed to cows during the early dry period before enrollment in this experiment was formulated to contain $75 \mathrm{mg}$ of $\mathrm{Zn} / \mathrm{kg}$ and $20 \mathrm{mg}$ of $\mathrm{Cu} / \mathrm{kg}$ (Mn information not available); all supplemental $\mathrm{Zn}, \mathrm{Cu}$, and $\mathrm{Mn}$ was from sulfate-based sources. Treatments were administered as premixes with trace mineral sources blended with calcium carbonate, rice hulls, and mineral oil (premix amount was $28 \mathrm{~g} / \mathrm{d}$ for all treatments during the prepartum and period and $70 \mathrm{~g} / \mathrm{d}$ for all treatments during the postpartum period) once daily by top-dressing and mixed well by hand into the top of each cow's daily allotment of TMR to ensure consumption.

Ingredient and chemical compositions of the diets fed during the experiment are described in Table 1. Formulated dietary ingredients and composition were typical of diets fed in the Northeastern United States, except that the mineral supplements fed omitted Zn, $\mathrm{Cu}, \mathrm{Mn}, \mathrm{Se}, \mathrm{Co}$, and I. All 3 experimental top-dress premixes also contained Se, Co, and I at targeted concentrations in the final TMR of $0.3 \mathrm{mg} / \mathrm{kg}$ (added), 0.4 $\mathrm{mg} / \mathrm{kg}$ (added), and $0.8 \mathrm{mg} / \mathrm{kg}$ (added), respectively. All nonforage ingredients were blended by a commercial feed mill into separate concentrate mixtures and diet mixing at the farm consisted of mixing the component forages with the appropriate concentrate mixture. Fresh feed was provided each morning at 0800 $\mathrm{h}$, orts were weighed and recorded daily, and water was available at all times. Samples of forages and concentrate mixtures were obtained weekly throughout the experiment, and DM content determined by drying at $55^{\circ} \mathrm{C}$ until constant weight. Amounts of individual feed components in the TMR were adjusted weekly based on changes in the DM content of these feed components. 
Table 1. Ingredient and chemical composition (DM basis, \% of DM unless otherwise noted) of experimental diets

\begin{tabular}{|c|c|c|}
\hline Item & Prepartum diet & Postpartum diet \\
\hline \multicolumn{3}{|l|}{ Ingredient } \\
\hline Corn silage, processed & 42.40 & 39.16 \\
\hline Wheat straw & 25.12 & 2.04 \\
\hline Legume silage & - & 16.31 \\
\hline Ground shelled corn & - & 7.51 \\
\hline Soybean meal & - & 5.10 \\
\hline Wheat middlings & - & 4.52 \\
\hline Corn germ meal & 8.18 & 3.60 \\
\hline Distillers grains (with solubles) & 6.99 & 5.12 \\
\hline Citrus pulp & - & 2.99 \\
\hline Cereal fines & - & 2.94 \\
\hline Soy Chlor ${ }^{1}$ & 3.26 & - \\
\hline Amino Plus ${ }^{2}$ & 3.22 & - \\
\hline Soybean hulls & 3.15 & 1.79 \\
\hline Canola meal & 3.21 & 2.59 \\
\hline Blood meal & - & 1.31 \\
\hline Molasses & 1.04 & 1.19 \\
\hline Bypass fat ${ }^{3}$ & - & 1.10 \\
\hline Alimet $^{4}$ & - & 0.10 \\
\hline Urea & - & 0.33 \\
\hline Calcium carbonate & 2.18 & 0.84 \\
\hline Calcium sulfate & 0.56 & - \\
\hline Sodium bicarbonate & - & 0.82 \\
\hline Potassium-magnesium-sulfate ${ }^{5}$ & 0.23 & - \\
\hline Potassium chloride & - & 0.08 \\
\hline Monodicalcium phosphate & 0.20 & - \\
\hline Salt & 0.11 & 0.40 \\
\hline Magnesium oxide & 0.09 & 0.11 \\
\hline Vitamin A, D, E premix ${ }^{6}$ & 0.05 & 0.03 \\
\hline Vitamin E premix ${ }^{7}$ & 0.02 & - \\
\hline Rumensin ${ }^{8}$ & 0.01 & 0.01 \\
\hline Biotin $1 \%$ & - & 0.06 \\
\hline \multicolumn{3}{|l|}{ Chemical composition $\left( \pm \mathrm{SD}^{9}\right)$} \\
\hline $\mathrm{CP}$ & $12.4(1.02)$ & $16.8(0.52)$ \\
\hline Soluble protein (\% of CP) & $32.7(5.34)$ & $43.3(3.84)$ \\
\hline $\mathrm{ADF}$ & $29.1(1.96)$ & $21.4(0.71)$ \\
\hline $\mathrm{NDF}$ & $47.6(3.9)$ & $33.9(1.1)$ \\
\hline Starch & $18.1(1.9)$ & $24.7(1.3)$ \\
\hline Sugar & $4.38(0.89)$ & $5.70(0.80)$ \\
\hline Ether extract & $2.95(0.33)$ & $3.80(0.16)$ \\
\hline Ash & $7.30(0.44)$ & $6.50(0.47)$ \\
\hline $\mathrm{Ca}$ & $1.25(0.10)$ & $0.84(0.06)$ \\
\hline $\mathrm{P}$ & $0.39(0.03)$ & $0.42(0.01)$ \\
\hline $\mathrm{K}$ & $1.12(0.05)$ & $1.47(0.06)$ \\
\hline $\mathrm{Mg}$ & $0.35(0.01)$ & $0.32(0.02)$ \\
\hline $\mathrm{Na}$ & $0.14(0.03)$ & $0.45(0.04)$ \\
\hline $\mathrm{Cl}$ & $0.52(0.02)$ & $0.48(0.07)$ \\
\hline $\mathrm{S}$ & $0.29(0.03)$ & $0.24(0.01)$ \\
\hline $\mathrm{Fe}, \mathrm{mg} / \mathrm{kg}$ & $232.2(21.8)$ & $205.1(26.0)$ \\
\hline $\mathrm{Zn}, \mathrm{mg} / \mathrm{kg}$ & $39.4(3.7)$ & $43.1(6.7)$ \\
\hline $\mathrm{Cu}, \mathrm{mg} / \mathrm{kg}$ & $6.0(1.4)$ & $7.7(1.3)$ \\
\hline $\mathrm{Mn}, \mathrm{mg} / \mathrm{kg}$ & $35.0(4.3)$ & $35.1(5.2)$ \\
\hline $\mathrm{DCAD}, \mathrm{mEq} / 100 \mathrm{~g}$ of $\mathrm{DM}^{10}$ & $2.0(2.2)$ & $29.0(1.6)$ \\
\hline
\end{tabular}

${ }^{1}$ Anionic feed supplement (West Central Cooperative, Ralston, IA).

${ }^{2}$ Rumen-undegradable protein supplement (AGP Inc., Omaha, NE).

${ }^{3}$ Prilled SFA (Cargill, Minnetonka, MN).

${ }^{4}$ D,L-2-Hydroxy-4-methylthiobutanoic acid (Novus International Inc., St. Louis, MO).

${ }^{5}$ Contained $18.8 \% \mathrm{~K}, 11.5 \% \mathrm{Mg}$, and $22.9 \%$ sulfate.

${ }^{6}$ Contained $30,464 \mathrm{IU}$ of vitamin $\mathrm{A} / \mathrm{kg}, 5,862 \mathrm{KIU}$ of vitamin $\mathrm{D} / \mathrm{kg}$, and $93,784 \mathrm{IU}$ of vitamin $\mathrm{E} / \mathrm{kg}$.

${ }^{7}$ Contained 499,400 IU of vitamin E/kg.

${ }^{8}$ Contained $200 \mathrm{~g}$ of monensin sodium/kg (Elanco Animal Health, Greenfield, IN).

${ }^{9}$ Standard deviation calculated from 5 and 7 samples for prepartum and postpartum diet, respectively.

${ }^{10}$ Calculated as mEq of $[(\mathrm{Na}+\mathrm{K})-(\mathrm{Cl}+\mathrm{S})] / 100 \mathrm{~g}$ of DM $(\mathrm{NRC}, 2001)$. 
Table 2. Basal diet concentrations, supplementation rates, and final total calculated diet concentrations of $\mathrm{Zn}$, $\mathrm{Cu}$, and $\mathrm{Mn}$ for cows fed varying sources during the periparturient period and early lactation

\begin{tabular}{|c|c|c|c|}
\hline \multirow[b]{2}{*}{ Item } & \multicolumn{3}{|c|}{ Diet $^{1}$} \\
\hline & ITM & ITM/OTM & HTM \\
\hline \multicolumn{4}{|l|}{ Prepartum period } \\
\hline Actual DMI, kg/d & 15.0 & 14.8 & 14.8 \\
\hline \multicolumn{4}{|l|}{$\mathrm{Zn}$} \\
\hline Basal diet, mg/kg & 39.4 & 39.4 & 39.4 \\
\hline Supplemented, mg/d & 600 & 600 & 600 \\
\hline Supplemented, mg/kg (calculated) & 40.0 & 40.5 & 40.5 \\
\hline Final total concentration, $\mathrm{mg} / \mathrm{kg}$ (calculated) & 79.4 & 79.9 & 79.9 \\
\hline \multicolumn{4}{|l|}{$\mathrm{Cu}$} \\
\hline Basal diet, mg/kg & 6.0 & 6.0 & 6.0 \\
\hline Supplemented, mg/d & 150 & 150 & 150 \\
\hline Supplemented, mg/kg (calculated) & 10.0 & 10.1 & 10.1 \\
\hline Final total concentration, $\mathrm{mg} / \mathrm{kg}$ (calculated) & 16.0 & 16.1 & 16.1 \\
\hline \multicolumn{4}{|l|}{$\mathrm{Mn}$} \\
\hline Basal diet, mg/kg & 35.0 & 35.0 & 35.0 \\
\hline Supplemented, mg/d & 400 & 400 & 400 \\
\hline Supplemented, mg/kg (calculated) & 26.7 & 27.0 & 27.0 \\
\hline Final total concentration, $\mathrm{mg} / \mathrm{kg}$ (calculated) & 61.7 & 62.0 & 62.0 \\
\hline \multicolumn{4}{|l|}{ Postpartum period } \\
\hline Actual DMI, kg/d & 25.4 & 24.5 & 25.8 \\
\hline \multicolumn{4}{|l|}{$\mathrm{Zn}$} \\
\hline Basal diet, mg/kg & 43.1 & 43.1 & 43.1 \\
\hline Supplemented, mg/d & 1,500 & 1,500 & 1,500 \\
\hline Supplemented, mg/kg (calculated) & 59.0 & 61.2 & 58.1 \\
\hline Final total concentration, mg/kg (calculated) & 102.1 & 104.3 & 101.2 \\
\hline \multicolumn{4}{|l|}{$\mathrm{Cu}$} \\
\hline Basal diet, mg/kg & 7.7 & 7.7 & 7.7 \\
\hline Supplemented, mg/d & 375 & 375 & 375 \\
\hline Supplemented, mg/kg (calculated) & 14.8 & 15.3 & 14.5 \\
\hline Final total concentration, $\mathrm{mg} / \mathrm{kg}$ (calculated) & 22.5 & 23.0 & 22.2 \\
\hline \multicolumn{4}{|l|}{$\mathrm{Mn}$} \\
\hline Basal diet, mg/kg & 35.1 & 35.1 & 35.1 \\
\hline Supplemented, mg/d & 1,000 & 1,000 & 1,000 \\
\hline Supplemented, mg/kg (calculated) & 39.4 & 40.8 & 38.7 \\
\hline Final total concentration, $\mathrm{mg} / \mathrm{kg}$ (calculated) & 74.5 & 75.9 & 73.8 \\
\hline
\end{tabular}

${ }^{1}$ ITM $=$ inorganic sources based upon sulfate forms of $\mathrm{Zn}, \mathrm{Cu}$, and $\mathrm{Mn}$; ITM/OTM = a blend (75:25) of trace minerals from sulfates and organic complexes of $\mathrm{Zn}, \mathrm{Cu}$, and $\mathrm{Mn} ; \mathrm{HTM}=$ hydroxy forms of $\mathrm{Zn}, \mathrm{Cu}$, and $\mathrm{Mn}$.

Dry matter contents of TMR were used in calculation of DMI for the corresponding week. Weekly samples of forages, concentrate mixtures, and TMR were composited into 4-wk composite samples and submitted to a commercial laboratory for Cornell Net Carbohydrate and Protein System/Cornell-Penn-Miner profiles (Cumberland Valley Analytical Services, Hagerstown, MD). Samples were analyzed for DM (method 930.15; AOAC International, 2000), CP (method 990.03; AOAC International, 2000), soluble protein (Krishnamoorthy et al., 1982), ADF (method 973.18; AOAC International, 2000), NDF (Van Soest et al., 1991), starch (Hall, 2009), sugar (DuBois et al., 1956), ether extract (method 2003.05; AOAC International, 2006), ash (method 942.05; AOAC International, 2000), and minerals (method 985.01; AOAC International, 2000).

Cows were milked twice daily (0900 and $2100 \mathrm{~h}$ ) and milk yields were recorded at all milkings for the 84-d postpartum treatment period. Milk samples were collected on the same day each week from both milkings.
Samples were composited and stored at $4^{\circ} \mathrm{C}$ with a preservative (bronopol tablet; D \& F Control Systems, San Ramon, CA) until analyzed (Dairy One Cooperative Inc., Ithaca, NY) within $24 \mathrm{~h}$ for fat, true protein, lactose, TS, and MUN using infrared analysis (method 972.160; AOAC International, 2000), and SCC by an optical fluorescent method (method 978.26; AOAC International, 2000). Body condition scores (1 to 5 scale; Wildman et al., 1982) and BW were measured weekly from the preliminary period through the whole treatment period. Gait scores were measured once during the week before assignment to treatment and at 4,8 , and 12 wk postpartum using a 5 -point scale $(1=$ normal to $5=$ severely lame; Sprecher et al., 1997).

\section{Plasma Sampling and Analyses}

Samples of blood were obtained from each cow via coccygeal blood vessel puncture on $1 \mathrm{~d}$ before assignment to treatment and once weekly from $21 \mathrm{~d}$ prepar- 
tum through $84 \mathrm{~d}$ postpartum. Plasma was harvested following centrifugation $\left(2,800 \times g\right.$ for $15 \mathrm{~min}$ at $\left.4^{\circ} \mathrm{C}\right)$, snap-frozen in liquid $\mathrm{N}$, and stored at $-20^{\circ} \mathrm{C}$ until analysis. Plasma samples collected from -3 wk prepartum through $12 \mathrm{wk}$ postpartum were analyzed for total antioxidant capacity (TAC) and TBARS. Plasma samples collected from 1 wk postpartum through 8 wk postpartum were analyzed for concentrations of haptoglobin $(\mathbf{H p})$. Plasma TAC was measured colorimetrically using a commercial kit (Antioxidant Assay Kit; Cayman Chemical Co., Ann Arbor, MI). The assay relied on the ability of antioxidants present in the samples to inhibit the oxidation of $2,2^{\prime}$-azino-di-(3ethylbenzthiazoline sulfonate) (ABTS). The capacity to prevent ABTS oxidation was compared with a water-soluble tocopherol analog and was expressed as millimolar concentrations. Plasma TBARS in samples was measured fluorometrically using a commercial kit (TBARS Assay Kit; Cayman Chemical Co.). In the assay, an adduct formed by the reaction of malondialdehyde in the samples and thiobarbituric acid under high temperature and acidic conditions was measured and expressed as micromolar concentrations. Plasma concentrations of $\mathrm{Hp}$ in samples were measured by enzymatic analysis (Phase Range Haptoglobin Assay; Tridelta Diagnostics Ltd., Morris Plains, NJ). In the assay, hemoglobin peroxidase activity is preserved by the binding of $\mathrm{Hp}$ in the samples to hemoglobin; the amount of activity was directly proportional to the amount of $\mathrm{Hp}$ in the sample. Spectrophotometric and fluorometric measurements were conducted using a VersaMax tunable microplate reader (Molecular Devices LLC, Sunnyvale, CA) and a Synergy HT MultiMode microplate reader (BioTek Instruments Inc., Winooski, VT), respectively.

\section{Endometrial Cytology}

Evaluation of endometrial cytology by low-volume lavage (Gilbert et al., 2005) was determined on all cows at $7 \mathrm{~d}$ postcalving (first lavage) and on $1 \mathrm{~d}$ between 40 and $60 \mathrm{~d}$ (second lavage) postcalving as previously described (Cheong et al., 2011). The perineum of the cow was cleansed and a 64-cm Flex Tip sterile plastic infusion pipette (Exodus Breeders Corp., York, PA) was manipulated through the cervix into the uterus. Sterile saline solution $(20 \mathrm{~mL})$ was injected into the uterus and agitated gently via the rectum; then, a sample of the fluid was aspirated. The recovered fluid was centrifuged $(58 \times g$; $3 \mathrm{~min}$; room temperature $)$ using a cytocentrifuge directly onto a glass slide. After drying, the slides were fixed and stained using a rapid Romanowsky-type staining procedure and examined at $400 \times$ magnification. Two hundred cells were counted from each slide, and results were expressed as the percentage of PMNL in total cells (excluding erythrocytes). All the slides were read, masked to treatment by the same investigator. The percentage of PMNL was compared among treatments as a continuous variable for both first and second lavage. Incidence of $\mathrm{CE}$ diagnosed with a cut-off point of 10\% PMNL (Cheong et al., 2011) was dichotomously analyzed in second lavage.

\section{Statistical Analyses}

Data from several cows were removed before data analysis because of health reasons. One cow assigned to ITM/OTM was removed from the entire study because she stepped on 2 teats during the prepartum period; therefore, the number of cows available for the prepartum analysis was 20, 19, and 20 for ITM, ITM/ OTM, and HTM treatments, respectively. In addition, 5 cows were removed from the postpartum data set due to severe health problems following parturition: 1 cow from the ITM treatment was removed because of the development of retained placenta, ketosis, and displaced abomasum; 3 cows were removed from the ITM/ OTM treatment (1 cow because of ketosis and hypocalcaemia; 1 cow due to ketosis, mastitis, and displaced abomasum; and 1 cow because of retained placenta and displaced abomasum); and 1 cow from the HTM treatment because of dystocia, retained placenta, and fever.

Data for DMI and milk yield were averaged to weekly means before analysis. Baseline values collected during the pretreatment week before assignment to treatment were used as covariates for DMI, BW, BCS, gait score, plasma TAC, and plasma TBARS concentration. Previous 305-d mature equivalent milk yields were used as covariates for milk yield and milk composition. Weekly variables were analyzed using PROC MIXED of SAS (version 9.1; SAS Institute Inc., Cary, NC) for a completely randomized design with repeated measures. Model terms were the fixed effects of covariate, treatment, week, and the interaction of treatment and week. The random effect was cow nested within treatment. For each weekly variable, cow was subjected to 4 covariance structures (first-order autoregressive, heterogeneous first-order autoregressive, compound symmetry, and heterogeneous compound symmetry) and the structure yielding the smallest Akaike information criterion was selected. The method of Kenward-Rogers was used for calculation of denominator degrees of freedom. Covariates were retained in the model if $P<0.10$. Consistent with our primary objective of comparing supplementation of HTM with 2 other common approaches for trace mineral supplementation to dairy cattle, single degree of freedom contrasts were used to test HTM versus ITM and HTM versus ITM/OTM. 
The percentage of PMNL in the total cells in lowvolume lavage was analyzed as a continuous variable for data collected during the first and second lavage. Incidence of $\mathrm{CE}$ was analyzed as a dichotomous variable using the cut point described above for second lavage. Statistical significance was declared at $P<0.05$ and trends were discussed at $0.05<P<0.10$. Least squares means and standard error of the mean are reported throughout.

\section{RESULTS}

Production results are presented in Table 3. Overall effects of HTM supplementation compared with either ITM or ITM/OTM on DMI, milk yield, and milk components (fat, true protein, and lactose) were not significant; however, cows fed HTM tended to have greater postpartum DMI than cows fed ITM/OTM (25.8 vs. $24.5 \mathrm{~kg} / \mathrm{d} ; P=0.07)$. An interaction of treatment and week existed $(P=0.02$; Figure 1$)$ for milk yield; however, differences of individual treatments were apparent only at wk-5 postpartum for the comparison of HTM versus ITM. This interaction was also present and similar for yields of $3.5 \% \mathrm{FCM}(P=0.03)$ and lactose $(P=$ 0.05 ; data not shown). Neither SCC nor concentrations of MUN were affected by treatment (Table 3).

The effects of trace mineral source on BW, BW change, BCS, and BCS change along with gait score are presented in Table 4. Cows fed HTM had higher BW

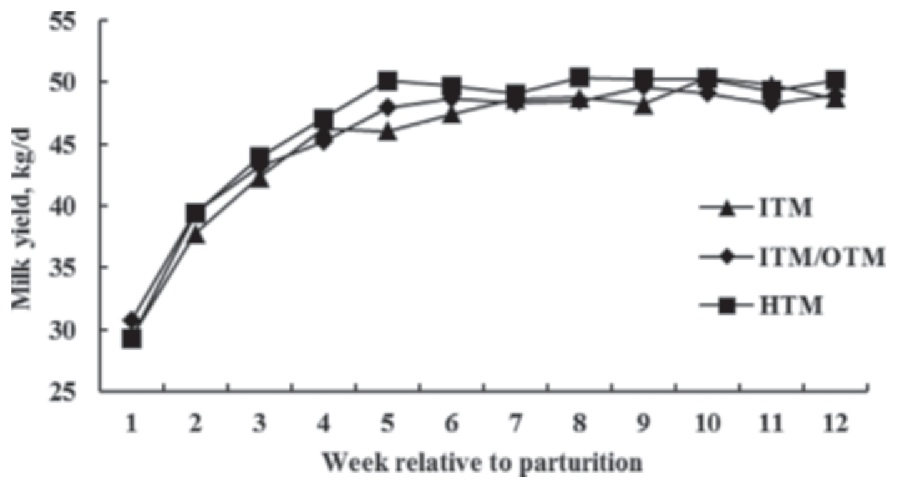

Figure 1. Milk yield for cows fed varying sources of $\mathrm{Zn}, \mathrm{Cu}$, and Mn during the periparturient period and early lactation. Values are LSM; $\mathrm{n}=19$ for inorganic sources based upon sulfates (ITM), $\mathrm{n}=$ 16 for $75: 25$ blend of sulfates and organic complexed sources (ITM/ OTM), and $\mathrm{n}=19$ for hydroxy trace minerals (HTM); SEM averaged $1.7 \mathrm{~kg} / \mathrm{d}$; the $P$-value for the interaction of treatment $\times$ week was 0.02 .

than those fed ITM during the prepartum period (765 vs. $719 \mathrm{~kg} ; P=0.02)$. During the postpartum period, cows fed HTM had higher BW than cows fed either ITM $(P=0.02)$ or ITM/OTM $(P=0.05)$. Despite these differences in BW, BW change was not affected by treatment. Neither BCS nor BCS change during either the prepartum or postpartum periods was affected by treatment. Gait scores were not affected by treatment.

Responses of plasma variables to supplementation with various sources of trace minerals are detailed in

Table 3. Least squares means for DMI, milk yield, and milk composition for cows fed varying sources of $\mathrm{Zn}$, Cu, and $\mathrm{Mn}$ during the periparturient period and early lactation

\begin{tabular}{|c|c|c|c|c|c|c|c|}
\hline Item & \multicolumn{3}{|c|}{ Treatment $^{1}$} & SEM & \multicolumn{3}{|c|}{$P$-value } \\
\hline \multicolumn{8}{|l|}{ DMI, kg/d } \\
\hline Prepartum & 15.0 & 14.8 & 14.8 & 0.3 & 0.68 & 0.93 & 0.68 \\
\hline Postpartum & 25.4 & 24.5 & 25.8 & 0.5 & 0.59 & 0.07 & 0.93 \\
\hline Fat, kg/d & 1.48 & 1.45 & 1.49 & 0.05 & 0.88 & 0.53 & 0.11 \\
\hline Protein, \% & 3.01 & 2.96 & 3.01 & 0.05 & 0.97 & 0.49 & 0.71 \\
\hline Protein, kg/d & 1.34 & 1.33 & 1.37 & 0.04 & 0.45 & 0.42 & 0.19 \\
\hline Lactose, \% & 4.71 & 4.70 & 4.66 & 0.04 & 0.29 & 0.39 & 0.94 \\
\hline Lactose, $\mathrm{kg} / \mathrm{d}$ & 2.14 & 2.16 & 2.18 & 0.05 & 0.54 & 0.76 & 0.05 \\
\hline $\mathrm{SCC}(\times 1,000)$ & 347 & 285 & 382 & 67 & 0.68 & 0.28 & 0.74 \\
\hline Urea $\mathrm{N}, \mathrm{mg} / \mathrm{dL}$ & 11.0 & 11.8 & 11.2 & 0.3 & 0.64 & 0.14 & 0.84 \\
\hline
\end{tabular}

${ }^{1}$ ITM $=$ inorganic sources based upon sulfates; ITM/OTM = a blend (75:25) of sulfates and organic sources; HTM = hydroxy trace minerals.

${ }^{2}$ Treatment $\times$ week interaction.

${ }^{3} \mathrm{FCM}=(0.4324 \times \mathrm{kg}$ of milk $)+(16.216 \times \mathrm{kg}$ of milk fat $)$.

${ }^{4} \mathrm{ECM}=(0.323 \times \mathrm{kg}$ of milk $)+(12.82 \times \mathrm{kg}$ of fat $)+(7.13 \times \mathrm{kg}$ of protein $)$. 
Table 4. Least squares means for BW, BW change, BCS, and BCS change and gait score for cows fed varying sources of Zn, Cu, and Mn during the periparturient period and early lactation

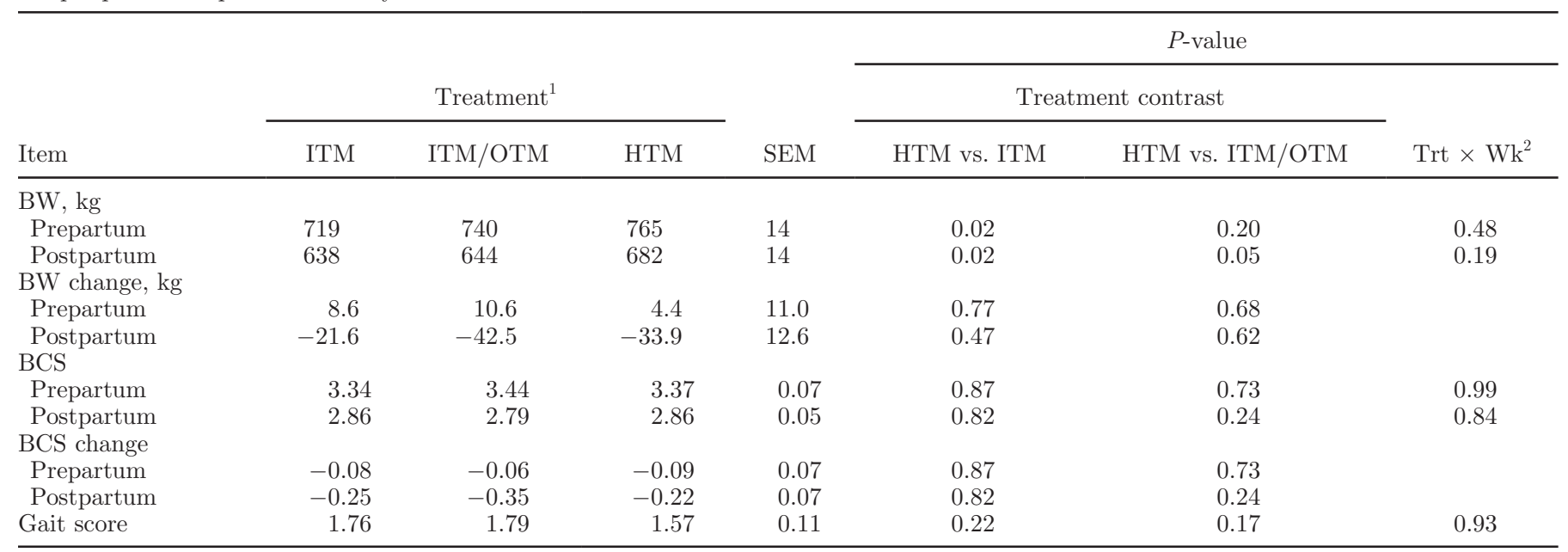

${ }^{1}$ ITM = inorganic sources based upon sulfates; ITM/OTM = a blend (75:25) of sulfates and organic sources; HTM = hydroxy trace minerals.

${ }^{2}$ Treatment $\times$ week interaction.

Table 5 and Figure 2. Cows fed HTM had lower plasma TAC than cows fed ITM during the overall study period (1.93 vs. $2.14 \mathrm{~m} M ; P=0.03$ ), the prepartum period (1.84 vs. $2.09 \mathrm{~m} M ; P=0.03$ ), and the postpartum period (1.95 vs. $2.16 \mathrm{mM} P=0.04$ ). Plasma TAC was not different for cows fed HTM versus ITM/OTM. Cows fed HTM tended to have lower plasma TBARS concentration during the entire study period compared with cows fed ITM (1.95 vs. $2.11 \mu M ; P=0.07$ ), but differences were not significant when analyzed separately for the prepartum and postpartum periods. Plasma TBARS concentration was not different in cows fed HTM compared with ITM/OTM. Plasma Hp concentration was not affected by treatment when assessed during the entire postpartum period; however, cows fed HTM tended to have lower Hp concentration than cows fed ITM/OTM during wk-1 postpartum (0.90 vs. 1.26 $\mathrm{mg} / \mathrm{mL} ; P=0.10$ )

The percentages of PMNL in both first and second lavage were not affected by treatments and the incidence of $\mathrm{CE}$ as assessed at second lavage was not affected by treatment (Table 6). One second lavage from 1 cow fed the ITM/OTM treatment was not obtained because of cervix deformity for unknown reasons, which resulted in 15 cows total for the ITM/OTM treatment.

\section{DISCUSSION}

Target and final concentrations of supplemental Zn, $\mathrm{Cu}$, and $\mathrm{Mn}$ were virtually identical across the 3 treatments during the postpartum period (Table 2). During the prepartum period, the final concentrations of supplemental $\mathrm{Zn}, \mathrm{Cu}$, and $\mathrm{Mn}$ were lower than targeted because cows consumed more of the prepartum diet than anticipated. However, prepartum DMI was virtually identical across treatments; therefore, final dietary concentrations of trace minerals of interest were lower than expected but similar among treatments (Table 2).

Effects of feeding HTM on milk yield and milk composition were not significant, with the exception of a treatment by time interaction for milk yield (Figure 1) and FCM yield (data not shown); this interaction was driven primarily by differences for cows fed HTM versus ITM at wk-5 postcalving. This is the first experiment to assess the effects of HTM supplementation on the performance of dairy cows during the periparturient period and early lactation; however, a meta-analysis of research conducted using organic forms of trace minerals has shown increased milk yield (Rabiee et al., 2010) when these forms are supplemented, although responses are heterogeneous. The organic forms are considered to have greater bioavailability than inorganic (sulfate or oxide) forms (Ammerman et al., 1995); therefore, we anticipated that feeding HTM sources that have been shown in steers (Spears et al., 2004) to have higher bioavailability than sulfates might also increase milk yield.

Few studies have reported effects of supplemental trace minerals on milk composition. The responses to feeding more bioavailable trace minerals vary across studies: no response for percentages and yield of milk components (Uchida et al., 2001), increased percentage of protein (Kincaid and Socha, 2004), increased yield of protein (Siciliano-Jones et al., 2008), and increased yield of fat and protein (Ballantine et al., 2002; Kellogg et al., 2003; Griffiths et al., 2007). The reason for the discrepancy among studies is unknown, although the 
Table 5. Plasma total antioxidant capacity (TAC), thiobarbituric acid reactive substances (TBARS), and haptoglobin (Hp) in cows fed varying sources of $\mathrm{Zn}, \mathrm{Cu}$, and $\mathrm{Mn}$ during the periparturient period and early lactation

\begin{tabular}{|c|c|c|c|c|c|c|c|}
\hline Item & \multicolumn{3}{|c|}{ Treatment $^{1}$} & SEM & \multicolumn{3}{|c|}{$P$-value } \\
\hline \multicolumn{8}{|l|}{$\mathrm{TAC}, \mathrm{m} M$} \\
\hline Whole study period ${ }^{3}$ & 2.14 & 2.07 & 1.93 & 0.07 & 0.03 & 0.17 & 0.94 \\
\hline Prepartum period ${ }^{4}$ & 2.09 & 1.93 & 1.84 & 0.08 & 0.03 & 0.45 & 0.85 \\
\hline Whole study period ${ }^{3}$ & 2.11 & 1.98 & 1.95 & 0.07 & 0.07 & 0.80 & 0.40 \\
\hline Prepartum period ${ }^{4}$ & 1.47 & 1.49 & 1.38 & 0.06 & 0.28 & 0.19 & 0.74 \\
\hline Postpartum period $^{5}$ & 2.26 & 2.11 & 2.10 & 0.09 & 0.15 & 0.91 & 0.23 \\
\hline \multicolumn{8}{|l|}{$\mathrm{Hp}, \mathrm{mg} / \mathrm{mL}$} \\
\hline Postpartum period $^{6}$ & 0.83 & 0.91 & 0.78 & 0.09 & 0.65 & 0.28 & 0.66 \\
\hline 1 wk postpartum 7 & 1.05 & 1.26 & 0.90 & 0.16 & 0.47 & 0.10 & - \\
\hline \multicolumn{8}{|c|}{$\overline{1}$ ITM $=$ inorganic sources based upon sulfates; ITM/OTM = a blend $(75: 25)$ of sulfates and chelated sources; HTM $=$ hydroxy trace minerals } \\
\hline \multicolumn{8}{|c|}{${ }^{5}$ Represents plasma samples collected weekly from 1 wk postpartum through 12 wk postpartum. } \\
\hline \multicolumn{8}{|c|}{${ }^{6}$ Represents plasma samples collected weekly from 1 wk postpartum through 8 wk postpartum. } \\
\hline
\end{tabular}

responses in component yields appear to be more related to milk production responses rather than changes in milk composition. A meta-regression analysis indicated that milk fat and protein percentages were not influenced by supplementation with a mixture of organic complexes of trace minerals, whereas protein and fat yields in milk were increased (Rabiee et al., 2010).

Few studies have reported temporal patterns of plasma markers related to oxidative stress during the periparturient period and early lactation. Plasma TAC represents gross antioxidant status, including both water- and fat-soluble antioxidants (Rice-Evans and Miller, 1994). Temporal patterns depicted in Figure 2 for plasma TAC (panel A) suggest that TAC was slightly greater during the postpartum period than the prepartum period. These results differ somewhat from those reported by Castillo et al. (2006) who reported that TAC was slightly greater during wk-1 postcalving than wk-4 and - 8 postpartum. Reasons for the difference in patterns between our results and those of Castillo et al. (2006) are not readily apparent, although performances of cows (both milk yield and DMI) were substantially (40 to $50 \%$ ) greater in our study. Furthermore, supplementation levels and strategies for vitamin and trace mineral nutrition were not described in the other study.

Plasma TBARS is considered to represent a composite number of lipid oxidative end products, including malondialdehyde (Bernabucci et al., 2005). Plasma TBARS concentrations appeared to decrease slightly as parturition approached, but then increased steadily during the postpartum period (Figure 2, panel B). This pattern is similar to those reported by Bernabucci et al. (2005) and Wullepit et al. (2012). In contrast, Castillo et al. (2006) reported that plasma malondialdehyde, which should largely reflect TBARS as suggested above, was elevated at wk-1 postpartum compared with subsequent weeks in lactation.

In the current experiment, plasma TAC was lower in cows fed HTM than cows fed ITM during the whole, prepartum, and postpartum study periods (Table 5). Plasma TBARS concentration tended to be lower in cows fed HTM than cows fed ITM during whole study period (Table 5). Although the treatment by time interaction was not significant, it appears that the overall trend was mostly driven by the patterns observed later in the postpartum period (Figure 2, panel B). This would support the concept that differences in response variables related to oxidative metabolism may require supplementation over a longer period of time. Our research group determined that feeding organic chelates of $\mathrm{Zn}, \mathrm{Cu}$, and $\mathrm{Mn}$ at $\mathrm{NRC}$ or commercial ( $2 \times$ of $\mathrm{NRC}$ ) levels decreased plasma TBARS concentration right after intramammary LPS challenge in mid-lactation cows compared with sulfate forms (Yasui et al., 2009). Lower plasma TAC in cows fed HTM may be due to less demand for antioxidant activity as a result of low plasma TBARS concentration or utilization of antioxidants that in turn contributed to the decreased TBARS concentration, although the temporal patterns of response in Figure 2 suggest that responses of TAC to 

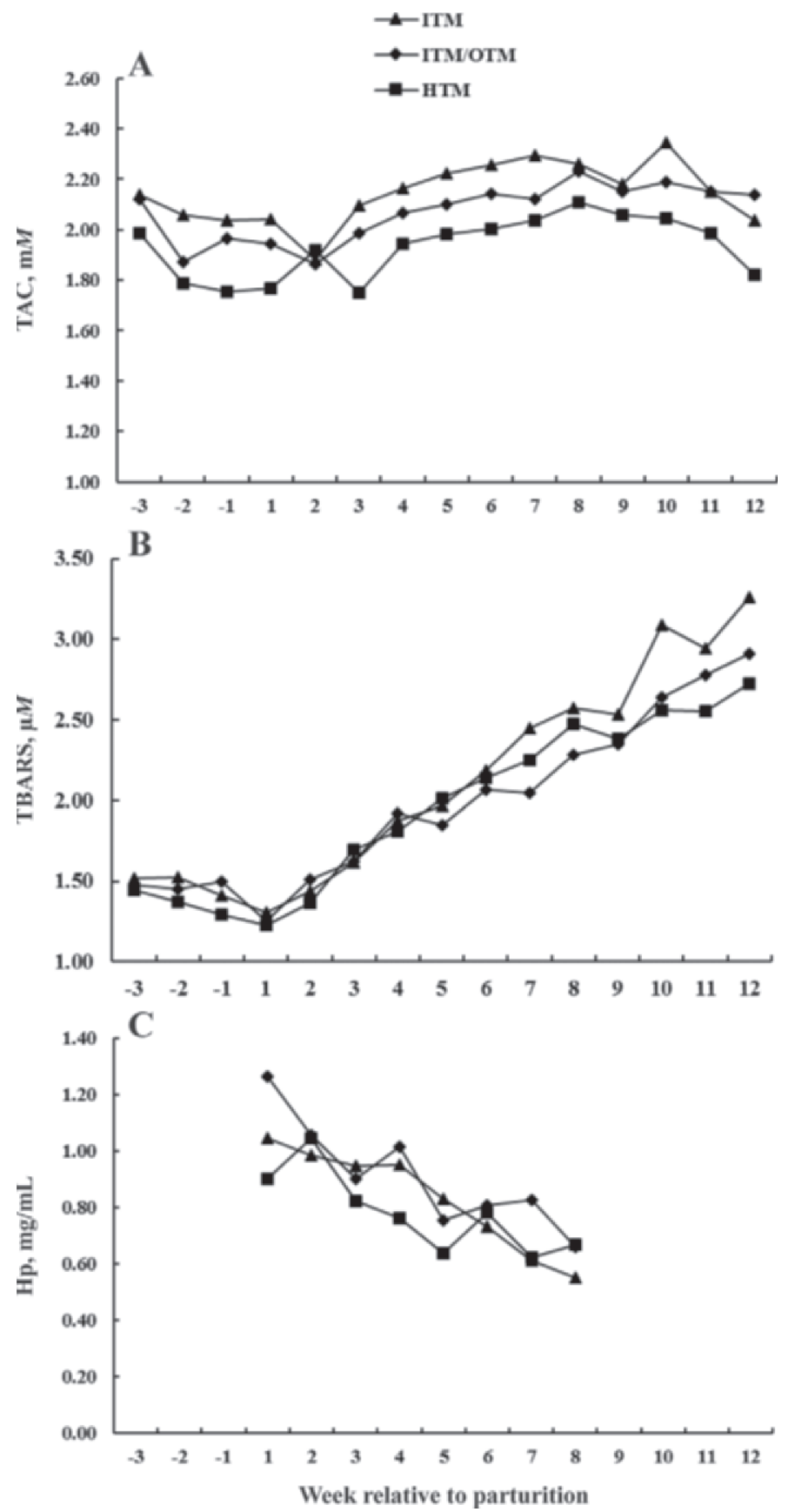

Figure 2. Plasma total antioxidant capacity (TAC; panel A), thiobarbituric acid reactive substances (TBARS; panel B), and haptoglobin (Hp; panel C) for cows fed varying sources of $\mathrm{Zn}, \mathrm{Cu}$, and $\mathrm{Mn}$ during the periparturient period and early lactation. Values are LSM; $\mathrm{n}=$ 19 for inorganic sources based upon sulfates (ITM), $\mathrm{n}=16$ for $75: 25$ blend of sulfates and organic complexed sources (ITM/OTM), and n $=19$ for hydroxy trace minerals (HTM); SEM averaged $0.10 \mathrm{mM}, 0.12$ $\mu M$, and $0.14 \mathrm{mg} / \mathrm{mL}$ for TAC, TBARS, and Hp, respectively. The $P$-values for the effect of treatment were $0.09,0.15$, and 0.55 for TAC, TBARS, and Hp, respectively. The $P$-values for the effect of week were $<0.01$ for all variables and the $P$-values for the interaction of treatment and week were $>0.40$ for all variables.

Journal of Dairy Science Vol. 97 No. 6, 2014
HTM supplementation existed across the entire treatment period, whereas responses of TBARS appeared to occur during the latter part of the treatment period. Further research is needed to elucidate the relationship between antioxidant status and oxidative stress response variables.

Concentrations of $\mathrm{Hp}$ in plasma were greatest during wk 1 and decreased steadily throughout the postpartum period (Figure 2, panel C). Effects of source of $\mathrm{Zn}, \mathrm{Cu}$, and $\mathrm{Mn}$ on plasma $\mathrm{Hp}$ concentration were not significant over the entire postpartum period; however, cows fed HTM tended to have lower plasma Hp concentration than those in the ITM/OTM treatment during the first week after parturition (Table 5). Acute-phase proteins such as Hp, serum amyloid A, and C-reactive protein are plasma proteins that increase in concentration following stimulus conditions such as infection, inflammation, or trauma (Eckersall, 2000). Haptoglobin is a notable acute-phase protein in ruminants, with a negligible circulating level in normal animals, but increases over 100-fold upon stimulation (Eckersall, 2000). Because cows fed HTM tended to have lower plasma Hp concentrations during the first week postcalving than cows fed ITM/OTM, it suggests that cows fed HTM had decreased systemic inflammation during the first week postcalving. Although it has been shown that serum Hp concentration within a week after parturition can be an indicator or risk factor to predict development uterine diseases such as metritis and CE in dairy cows (Huzzey et al., 2009; Chan et al., 2010; Dubuc et al., 2010), the lack of treatment differences in uterine cytology suggests that elevated Hp concentrations immediately postpartum may not be a major risk factor for subsequent development of CE.

Effects of sources of $\mathrm{Zn}, \mathrm{Cu}$, and $\mathrm{Mn}$ on the extent of influx of PMNL to the uterus at $7 \mathrm{~d}$ and $1 \mathrm{~d}$ between 40 and $60 \mathrm{~d}$ postpartum were not significant (Table 6). The reason for the lack of response of uterine cytology to various sources of trace minerals in the current study is unknown. Our results showed around $40 \%$ of PMNL influx at $7 \mathrm{~d}$ postpartum among all treatments. Gilbert et al. (2007) showed the median proportion of PMNL at 0,7 , and $21 \mathrm{~d}$ postpartum was 37,20 , and $41 \%$, respectively. Therefore, all of the cows in the current study may have had somewhat higher percentages of PMNL compared with those in previous research. During the early postpartum period, increased infiltration of the uterus with PMNL may indicate that cows in this study had relatively robust immune function. This speculation is supported by an overall low $(\sim 35 \%)$ subsequent incidence of $\mathrm{CE}$ in cows in this experiment. Previous research (Gilbert et al., 2005) conducted on commercial dairy farms determined that $\mathrm{CE}$ rates ranges from 37 to $74 \%$ of cows. 
Table 6. Percentages of neutrophils in first and second uterine lavage and incidence of cytological endometritis (CE) in second uterine lavage from cows fed varying sources of $\mathrm{Zn}, \mathrm{Cu}$, and $\mathrm{Mn}$ during the periparturient period and early lactation

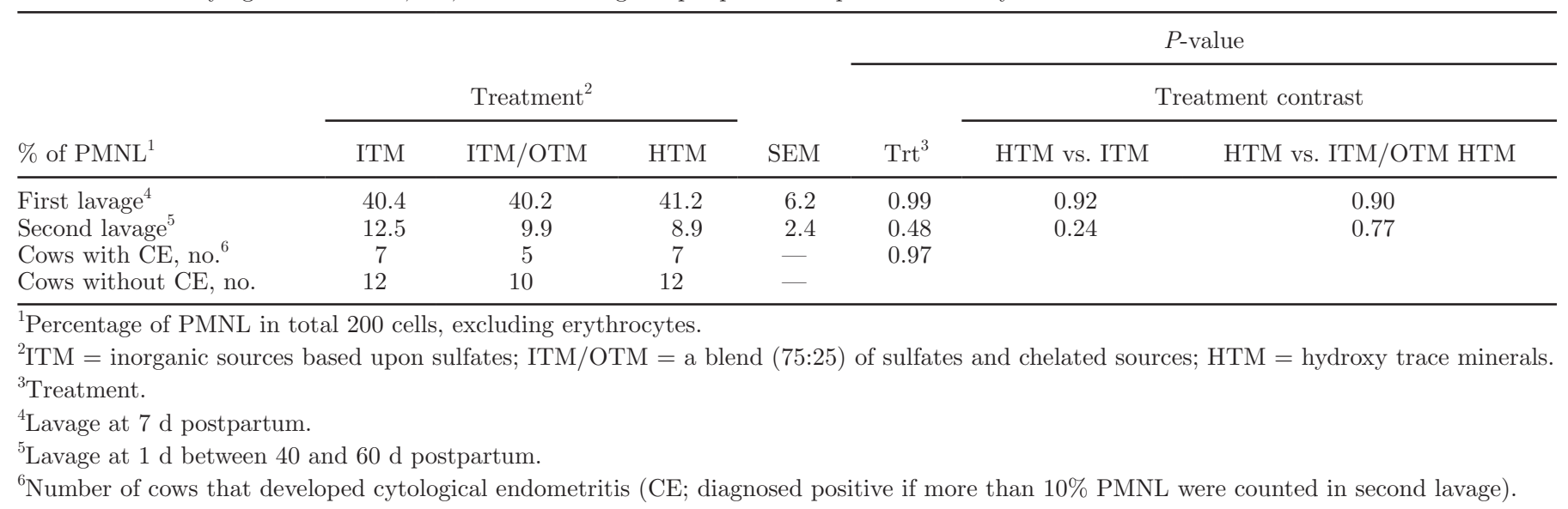

Consistent with the result of PMNL percentage, treatments effects on incidence of $\mathrm{CE}$ at 40 to $60 \mathrm{~d}$ postpartum were also not significant (Table 4) and the overall incidence was relatively low, as indicated above. These results suggest that trace mineral source at the levels of trace mineral supplementation studied does not affect CE. Other studies clearly have illustrated relationships of CE with Ca status (Martinez et al., 2012) and energy status (Hammon et al., 2006), suggesting that $\mathrm{Zn}, \mathrm{Cu}$, and $\mathrm{Mn}$ nutrition are less important nutritional factors in the etiology of CE.

\section{CONCLUSIONS}

Supplementation of hydroxy sources of $\mathrm{Zn} \mathrm{Cu}$, and $\mathrm{Mn}$ during the transition period and early lactation modulated plasma markers related to oxidative metabolism, resulting in trends for decreased TBARS concentration and decreased TAC compared with supplementation of these minerals as sulfates. Overall effects of treatment on milk yield and composition were not significant. Differences between hydroxy sources and a blend of sulfates and organic complexes of $\mathrm{Zn}, \mathrm{Cu}$, and $\mathrm{Mn}$ were not significant for virtually all outcome variables. Trace mineral source did not affect endometrial cytology and the incidence of $\mathrm{CE}$ in this experiment.

\section{ACKNOWLEDGMENTS}

The authors sincerely appreciate the assistance of the following students and staff at Cornell University (Ithaca, NY) in completing the study: S. H. Cheong, S. Pelton, K. Donnan, S. Honda, Z. Hernandez, V. Kim, E. Diehl, A. Jones, Y. Bing, E. Martens, B. Pomeroy, J. Huzzey, K. Schoenberg, R. Higgs, and the staff at the Cornell University Dairy Teaching and Research Cen- ter. Partial funding for this experiment was provided by Micronutrients Inc. (Indianapolis, IN).

\section{REFERENCES}

Ammerman, C. B., D. H. Baker, and A. J. Lewis. 1995. Bioavailability of Nutrients for Animals: Amino Acids, Minerals, and Vitamins. Academic Press, San Diego, CA.

Andrieu, S. 2008. Is there a role for organic trace element supplements in transition cow health? Vet. J. 176:77-83.

AOAC International. 2000. Official Methods of Analysis. 17th ed. AOAC International, Arlington, VA.

AOAC International. 2006. Official Methods of Analysis. 18th ed. AOAC International, Eden Prairie, MN.

Ballantine, H. T., M. T. Socha, D. J. Tomlinson, A. B. Johnson, A. S. Fielding, J. K. Shearer, and S. R. Van Amstel. 2002. Effects of feeding complexed zinc, manganese, copper, and cobalt to late gestation and lactating dairy cows and claw integrity, reproduction, and lactation performance. Prof. Anim. Sci. 18:211-218.

Bernabucci, U., B. Ronchi, N. Lacetera, and A. Nardone. 2005. Influence of body condition score on relationships between metabolic status and oxidative stress in periparturient dairy cows. J. Dairy Sci. 88:2017-2026.

Castillo, C.. J. Hernández, I. Valverde, V. Pereira, J. Sotillo, M. López Alonso, and J. L. Benedito. 2006. Plasma malonaldehyde (MDA) and total antioxidant status (TAS) during lactation in dairy cows. Res. Vet. Sci. 80:133-139.

Chan, J. P.-W., C.-C. Chang, W.-L. Hsu, W.-B. Liu, and T.-H. Chen. 2010. Association of increased serum acute-phase protein concentrations with reproductive performance in dairy cows with postpartum metritis. Vet. Clin. Pathol. 39:72-78.

Cheong, S. H., D. V. Nydam, K. N. Galvão, B. M. Crosier, and R. O. Gilbert. 2011. Cow-level and herd-level risk factors for subclinical endometritis in lactating Holstein cows. J. Dairy Sci. 94:762-770.

DuBois, M., K. A. Gilles, J. K. Hamilton, P. A. Rebers, and F. Smith. 1956. Colorimetric method for determination of sugars and related substances. Anal. Chem. 28:350-356.

Dubuc, J., T. F. Duffield, K. E. Leslie, J. S. Walton, and S. J. LeBlanc. 2010. Risk factors for postpartum uterine diseases in dairy cows. J. Dairy Sci. 93:5764-5771.

Eckersall, P. 2000. Recent advances and future prospects for the use of acute phase proteins as markers of disease in animals. Rev. Med. Vet. (Toulouse) 151:577-584.

Enjalbert, F., P. Lebreton, and O. Salat. 2006. Effects of copper, zinc and selenium status on performance and health in commercial dairy and beef herds: Retrospective study. J. Anim. Physiol. Anim. Nutr. (Berl.) 90:459-466. 
Formigoni, A., M. Fustini, L. Archetti, S. Emanuele, C. Sniffen, and G. Biagi. 2011. Effects of an organic source of copper, manganese and zinc on dairy cattle productive performance, health status and fertility. Anim. Feed Sci. Technol. 164:191-198.

Fry, R. S., M. S. Ashwell, K. E. Lloyd, A. T. O'Nan, W. L. Flowers, K. R. Stewart, and J. W. Spears. 2012. Amount and source of dietary copper affects small intestine morphology, duodenal lipid peroxidation, hepatic oxidative stress, and mRNA expression of hepatic copper regulatory proteins in weanling pigs. J. Anim. Sci. 90:3112-3119.

Gilbert, R., N. Santos, K. Galvão, S. Brittin, and H. Roman. 2007. The relationship between postpartum uterine bacterial infection (BI) and subclinical endometritis (SE). J. Dairy Sci. 90(Suppl. 1):469. (Abstr.)

Gilbert, R. O., S. T. Shin, C. L. Guard, H. N. Erb, and M. Frajblat. 2005. Prevalence of endometritis and its effects on reproductive performance of dairy cows. Theriogenology 64:1879-1888.

Griffiths, L. M., S. H. Loeffler, M. T. Socha, D. J. Tomlinson, and A. B. Johnson. 2007. Effects of supplementing complexed zinc, manganese, copper and cobalt on lactation and reproductive performance of intensively grazed lactating dairy cattle on the South Island of New Zealand. Anim. Feed Sci. Technol. 137:69-83.

Hall, M. B. 2009. Determination of starch, including maltooligosaccharides, in animal feeds: Comparison of methods and a method recommended for AOAC collaborative study. J. AOAC Int. 92:42-49.

Hammon, D. S., I. M. Evjen, T. R. Dhiman, J. P. Goff, and J. L. Walters. 2006. Neutrophil function and energy status in Holstein cows with uterine health disorders. Vet. Immunol. Immunopathol. 113:21-29.

Huzzey, J. M., T. F. Duffield, S. J. LeBlanc, D. M. Veira, D. M. Weary, and M. A. G. von Keyserlingk. 2009. Short communication: Haptoglobin as an early indicator of metritis. J. Dairy Sci. 92:621-625.

Kellogg, D. W., M. T. Socha, D. J. Tomlinson, and A. B. Johnson. 2003. Review: Effects of feeding cobalt glucoheptonate and metal specific amino acid complexes of zinc, manganese, and copper on lactation and reproductive performance of dairy cows. Prof. Anim. Sci. 19:1-9.

Kincaid, R. L., and M. T. Socha. 2004. Inorganic versus complexed trace mineral supplements on performance of dairy cows. Prof. Anim. Sci. 20:66-73.

Krishnamoorthy, U., T. V. Muscato, C. J. Sniffen, and P. J. Van Soest. 1982. Nitrogen fractions in selected feedstuffs. J. Dairy Sci. $65: 217-225$.

Martinez, N., C. A. Risco, F. S. Lima, R. S. Bisinotto, L. F. Greco, E. S. Ribeiro, F. Maunsell, K. Galvão, and J. E. P. Santos. 2012. Evaluation of peripartal calcium status, energetic profile, and neutrophil function in dairy cows at low or high risk of developing uterine disease. J. Dairy Sci. 95:7158-7172.

NRC. 2001. Nutrient Requirements of Dairy Cattle. 7th rev. ed. National Academy Press, Washington, DC.

Nemec, L. M., J. D. Richards, C. A. Atwell, D. E. Diaz, G. I. Zanton, and T. F. Gressley. 2012. Immune responses in lactating Holstein cows supplemented with $\mathrm{Cu}, \mathrm{Mn}$, and $\mathrm{Zn}$ as sulfates or methionine hydroxy analogue chelates. J. Dairy Sci. 95:4568-4577.

Nocek, J. E., M. T. Socha, and D. J. Tomlinson. 2006. The effect of trace mineral fortification level and source on performance of dairy cattle. J. Dairy Sci. 89:2679-2693.
Rabiee, A. R., I. J. Lean, M. A. Stevenson, and M. T. Socha. 2010. Effects of feeding organic trace minerals on milk production and reproductive performance in lactating dairy cows: A meta-analysis. J. Dairy Sci. 93:4239-4251.

Rice-Evans, C., and N. Miller. 1994. Total antioxidant status in plasma and body fluids. Methods Enzymol. 234:279-293.

Scaletti, R. W., D. S. Trammell, B. A. Smith, and R. J. Harmon. 2003. Role of dietary copper in enhancing resistance to Escherichia coli mastitis. J. Dairy Sci. 86:1240-1249.

Sharma, N., N. K. Singh, O. P. Singh, V. Pandey, and P. K. Verma. 2011. Oxidative stress and antioxidant status during transition period in dairy cows. Asian-australas. J. Anim. Sci. 24:479-484.

Sheldon, I. M., J. Cronin, L. Goetze, G. Donofrio, and H. Schuberth. 2009. Defining postpartum uterine disease and the mechanisms of infection and immunity in the female reproductive tract in cattle. Biol. Reprod. 81:1025-1032.

Siciliano-Jones, J. L., M. T. Socha, D. J. Tomlinson, and J. M. DeFrain. 2008. Effect of trace mineral source on lactation performance, claw integrity, and fertility of dairy cattle. J. Dairy Sci. 91:1985-1995.

Sordillo, L. M., and S. L. Aitken. 2009. Impact of oxidative stress on the health and immune function of dairy cattle. Vet. Immunol Immunopathol. 128:104-109.

Spears, J. W., E. B. Kegley, and L. A. Mullis. 2004. Bioavailability of copper from tribasic copper chloride and copper sulfate in growing cattle. Anim. Feed Sci. Technol. 116:1-13.

Spears, J. W., and W. P. Weiss. 2008. Role of antioxidants and trace elements in health and immunity of transition dairy cows. Vet. J. $176: 70-76$

Sprecher, D. J., D. E. Hostetler, and J. B. Kaneene. 1997. A lameness scoring system that uses posture and gait to predict dairy cattle reproductive performance. Theriogenology 47:1179-1187.

Uchida, K., P. Mandebvu, C. S. Ballard, C. J. Sniffen, and M. P. Carter. 2001. Effect of feeding a combination of zinc, manganese and copper amino acid complexes, and cobalt glucoheptonate on performance of early lactation high producing dairy cows. Anim. Feed Sci. Technol. 93:193-203.

Van Soest, P. J., J. B. Robertson, and B. A. Lewis. 1991. Methods for dietary fiber, neutral detergent fiber, and nonstarch polysaccharides in relation to animal nutrition. J. Dairy Sci. 74:3583-3597.

Wildman, E. E., G. M. Jones, P. E. Wagner, R. L. Boman, H. F. Troutt Jr., and T. N. Lesch. 1982. A dairy cow body condition scoring system and its relationship to selected production characteristics. J. Dairy Sci. 65:495-501.

Wullepit, N., M. Hostens, C. Ginneberge, V. Fievez, G. Opsomer, D. Fremaut, and S. De Smet. 2012. Influence of a marine algae supplementation on the oxidative status of plasma in dairy cows during the periparturient period. Prev. Vet. Med. 103:298-303.

Yasui, T., R. M. Ehrhardt, G. R. Bowman, M. Vazquez-Anon, J. D Richards, C. A. Atwell, T. D. Wineman, and T. R. Overton. 2009. Effects of trace mineral amount and source on aspects of oxidative status and immune function in dairy cows. J. Dairy Sci. 92(E. Suppl. 1):725. (Abstr.) 